UDC 617.735-007.23:69

DOI: 10.15587/2519-4798.2021.219921

\title{
ENTEROSGEL ROLE IN NEURODEGENERATIVE CHANGES IN THE RETINA RATS UNDER THE INFLUENCE OF CR (VI) - INDUCED RETINOPATHY BY STUDY MORPHOLOGICAL CHANGES IN DYNAMIC
}

\author{
O. Kuzenko, Ye. Kuzenko, Yu. Demin
}

\begin{abstract}
Chromium galvanic production have leaded to biosphere pollution. Therefore advisable to study of role in the neurodegenerative development in retinal diseases under experimental conditions.

The aim is to study the Enterosgel effect on morphological changes in rats retina with Cr(VI) - induced retinopathy. Materials and methods. An experimental study had carried out on 72 outbred white male rats. The rats had divided into 3 groups: I - control group of intact rats $(n=24)$. Control rats were received drinking water, II group - rats $(n=24)$, were received drinking water with $\mathrm{Cr}(\mathrm{VI})\left(\mathrm{K}_{2} \mathrm{Cr}_{2} \mathrm{O}_{7}\right)-0.02 \mathrm{~mol} / \mathrm{L}$, III group - animals $(n=24)$ were received drinking water with $\mathrm{K}_{2} \mathrm{Cr}_{2} \mathrm{O}_{7}-0.02 \mathrm{~mol} / \mathrm{L}$ and hydrogel methylsilicic acid (Enterosgel) at a dose of $0.8 \mathrm{mg} / \mathrm{kg}$ per day as a corrector. The animals had been decapitated under ether anesthesia. The retina had been studied on days 20, 40 and 60 of the experiment. Morphologically and morphometrically they had analyzed.
\end{abstract}

Results. According to histological studies, it has proved that $\mathrm{Cr}$ (VI) causes dystrophic and degenerative changes in all rats retina layers. They increase as the duration of the experiment. The use of Enterosgel as a corrective therapy showed positive results in restoring the morphological structure of rats retina. After Enterosgel 20 days using as a corrector of Cr (VI) exposure, there is a barely noticeable swelling of the outer and inner nuclear layers. Other layers of the retina, morphologically, look undamaged. Forty days Enterosgel treatment have outer and inner nuclear layer edema of retina of animals persists but does not increase. It is easy noticeable swelling of the outer and inner layers of mesh, but no signs of damage processes of cell populations nuclear layers. State ganglionic layer and nerve fiber layer entirely satisfactory. These pathological changes are not critical. After 60 days from the beginning of loading of Cr (VI) and application of Enterosgel in the retina of rats there are initial degenerative changes in the photosensory layer. Cystic dilated outer segments of rods and cones were visible throughout, and areas of their fragmentation were observed. Ganglion neurons are not damaged, but their axons appear somewhat thickened and fluffy. But in general, the typical structure of the retina is preserved.

Conclusions. Chromium-induced toxicity in rats is characterized by pronounced histological and morphometric changes and retinal thickness, which appear after 20 days, increase by 40 days and acquire maximum transformations after 60 days of the experiment. The use of Enterosgel improves picture morphological structures of the retina in rats under the influence of $\mathrm{Cr}(\mathrm{VI})$. The changes were expressed on days 20 and 40, which indicates the presence of protective properties for the retina

Keywords: hexavalent chromium, retina, toxicity experiment, enterosgel, morphology, morphometry

Copyright (C 2021, O. Kuzenko, Ye. Kuzenko, Yu. Demin.

This is an open access article under the CC BY license (http://creativecommons.org/licenses/by/4.0).

\section{Introduction}

In the structure of diseases of the population of Ukraine, ophthalmic pathology accounts for $5.2 \%$ of the total number of diseases and occupies the sixth place, which allows it to be one of the most common groups in the structure of total morbidity in Ukraine [1]. According to The European Chemicals Agency (ECHA), every third case of the disease on the planet is associated with a chemical factor [2].

Scientists' interest in this problem has grown significantly, as evidenced by the appearance of a number of mostly foreign publications, which in their studies focus on anthropogenic environmental factors, namely, heavy metals, as one of the main causes of ophthalmic pathology and their severity. Elevated levels of lead [3] were found in the blood of patients with glaucoma, cadmium - in patients with age-related macular degeneration [4], mercury - in patients with dry eye syndrome [5]. The authors consider them a risk factor for these diseases.

One of the most toxic elements that pollutes the biosphere is hexavalent chromium [6]. It is well known that the main sources of contamination with hexavalent chromium compounds are galvanic production, waste from tanneries, circulating cooling systems, production of glue, detergents [7].

Of interest are the toxic optical neuropathy and retinopathy described in the literature, which occurs several years after implantation of an endoprosthesis, the components of which are Co (II) and Cr (VI) [8, 9]. According to the authors, the toxic role of $\mathrm{Cr}$ (VI) is controversial, as it remains unclear [10].

The aim of the research - to study the effect of Enterosgel on the histostructure and dynamics of morphometric changes in the retina of rats with $\mathrm{Cr}$ (VI) induced retinopathy.

\section{Materials and methods}

The experimental study was conducted on 72 outbred white adult male rats on the basis of the Center for Pathomorphological Research of the Medical Institute of Sumy State University in September - December 2018. The experiment strictly adhered to the "General Ethical 
Principles of Animal Experiments" adopted by the First National Congress on Bioethics (Kyiv, 2001), the provisions of the Declaration of Helsinki (World Medical Association General Assembly, 2008), norms and principles of the "European Convention for the Protection of Vertebrates animals used for experimental purposes" (Strasbourg, 1986).

To assess the retinoprotective properties of the hydrogel of methylsilicic acid (Enterosgel) on the background of $\mathrm{Cr}$ (VI) - induced retinopathy in the studied rats were divided into 3 groups: I - control group of intact rats $(n=24)$, group II - rats $(n=24)$ who received drinking water enriched with $\mathrm{Cr}$ (VI) $\left(\mathrm{K}_{2} \mathrm{Cr}_{2} \mathrm{O}_{7}\right)-$ $0.02 \mathrm{~mol} / \mathrm{l}$, which is typical for the northern regions of Sumy region [11] and group III - animals $(n=24)$ who consumed water saturated with $\mathrm{K}_{2} \mathrm{Cr}_{2} \mathrm{O}_{7}$ (access to water was free) and as a corrector Enterosgel (paste for oral use "Enterosgel", EOF "KREOMA-PHARM", Ukraine) at a dose of $0.8 \mathrm{mg} / \mathrm{kg}$ per day. For adults, the daily therapeutic and prophylactic dose of Enterosgel is $45 \mathrm{mg}$ per day. According to [12] recommendations, the dose of the drug for rats was calculated taking into account the species according to the formula proposed by $\mathrm{Yu}$. R. Rybolovlev and R. S. Rybolovlev [13]. Enterosgel rats were administered orally with a pipette once a day at 9:00 am. Food pauses were maintained for 2 hours thereafter. Control rats received normal water.

Animals were removed from the experiment under ether anesthesia and enucleation of the eyeballs was performed to assess morphological changes in the retina without the introduction of enterosgel and with the introduction of enterosgel in three terms - after 20, 40 and 60 days of the experiment. Preparation of material for histological examination was performed according to generally accepted methods (Merkulov G.A., 1969). Retinal preparations for optical examination were stained with hematoxylin and eosin. The samples were analyzed using a light microscope "Carl Zeiss Primo Star" (Germany) with a digital camera ("Zeiss AxioCam ERc 5s" with lenses 4, 10×40 and binoculars 10), (Germany). Morphometric measurements of the retina were performed using the Digimazer program. All micrometric indicators are presented in units of length according to the International System of Units $-10^{-6} \mathrm{~m}(\mu \mathrm{m})$.

Statistical data processing was performed by the method of variation statistics using Microsoft Excel 2007. Determination of the significance of differences was performed using t-Student's t test $(\mathrm{t})$.

The results of the methods used were considered statistically significant with an error probability of $\mathrm{p}<0.05$.

\section{Research results}

Under light microscopy, the retina of rats of control group (I) had a character similar to the human retina with a clearly differentiated structure and is represented by 11 layers [14] (Fig. 1). Namely: the Bruch's membrane (some researchers attribute it to both the choroid and the retina), pigment epithelium, layer of photosensory cells (PL), outer boundary membrane, outer nuclear layer (ONL), outer plexiglass (mesh) layer (OML), inner nuclear layer (INL), inner plexiglass (mesh) layer (IML), layer of ganglion cells (GL), layer of nerve fibers (LNF) and an inner boundary membrane that separates the retina from the vitreous.

The retinal thickness of intact animals weighing approximately $200 \mathrm{~g}$ was $186.55 \pm 4.07 \mu \mathrm{m}$. Morphometric indicators of the thickness of the retinal layers of all experimental groups are presented in Table 1. The nuclear layers of the retina and the outer reticular layer occupy a larger volume in the overall structure of the retina.

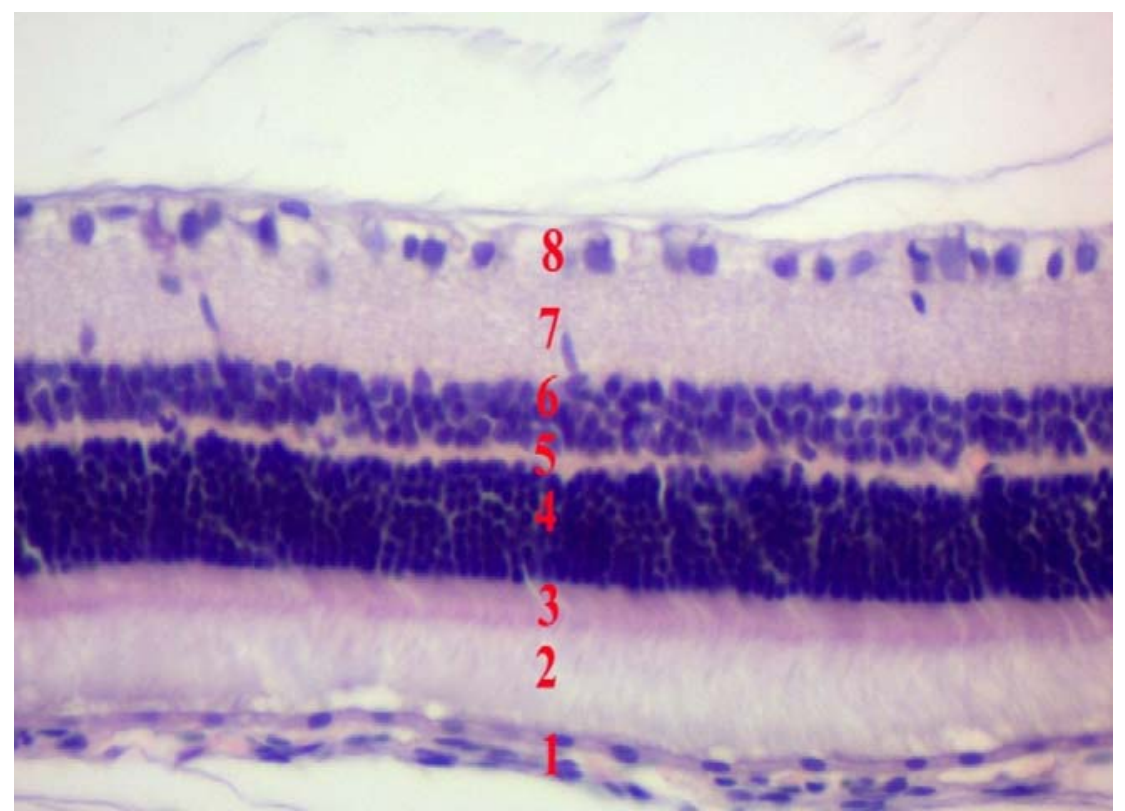

Fig. 1. The retina of the control (I) group of experimental rats. Hematoxylin and eosin staining. Magnification $\times 400$. Designation: 1 - retinal pigment epithelium; 2 - outer segments of photoreceptors; 3 - internal segments of photoreceptors; 4 - outer nuclear layer; 5 - outer plexiglass layer; 6 - inner nuclear layer; 7 - inner plexiglass layer; 8 - a layer of ganglion cells and a layer of nerve fibers 
Table 1

The thickness of the retinal layers of rats of control and experimental groups $(\mathrm{M} \pm \mathrm{m}, \mu \mathrm{m})$

\begin{tabular}{|l|c|c|c|c|c|c|c|}
\hline \multirow{2}{*}{$\begin{array}{l}\text { Layers of } \\
\text { the retina }\end{array}$} & \multirow{2}{*}{$\begin{array}{c}\text { Control } \\
(\mathrm{n}=24)\end{array}$} & \multicolumn{3}{|c|}{ Experimental group II [Cr (VI)], $\mathrm{n}=24$} & \multicolumn{3}{|c|}{$\begin{array}{l}\text { Experimental group III [Cr (VI) + Enter- } \\
\text { osgel], } \mathrm{n}=24\end{array}$} \\
\cline { 3 - 8 } & & 20 days & 40 days & 60 days & 20 days & 40 days & 60 days \\
\hline PL & $35.2 \pm 0.2$ & $35.9 \pm 1.1$ & $35.6 \pm 0.2$ & $35.5 \pm 0.6$ & $36.3 \pm 0.3$ & $35.6 \pm 1.8$ & $38.2 \pm 1.8^{*}$ \\
\hline ONL & $38.5 \pm 0.9$ & $38.9 \pm 0.4$ & $39.4 \pm 1.1^{*}$ & $41.3 \pm 1.4^{* *}$ & $37.2 \pm 1.5$ & $38.4 \pm 1.1$ & $38.6 \pm 1.7$ \\
\hline OML & $11.3 \pm 0.9$ & $11.9 \pm 0.3$ & $12.1 \pm 0.4$ & $13.6 \pm 1.2^{*}$ & $12.3 \pm 0.6$ & $13.1 \pm 1.1^{*}$ & $13.4 \pm 1.6^{*}$ \\
\hline INL & $28.9 \pm 0.2$ & $30.9 \pm 1.3^{*}$ & $40.3 \pm 2.1^{* *}$ & $43.2 \pm 2.5^{* *}$ & $29.3 \pm 0.9$ & $28.4 \pm 1.8$ & $30.9 \pm 1.5^{*}$ \\
\hline IML & $55.7 \pm 1.7$ & $57.4 \pm 1.9^{*}$ & $61.7 \pm 2.5^{* *}$ & $67.8 \pm 3.6^{*}$ & $55.5 \pm 0.2$ & $57.1 \pm 0.7^{*}$ & $58.1 \pm 1.1^{*}$ \\
\hline GL + & $16.9 \pm 0.8$ & $16.2 \pm 0.3$ & $15.3 \pm 1.4$ & $15.3 \pm 0.5$ & $17.7 \pm 1.1$ & $17.8 \pm 0.9$ & $17.8 \pm 0.9$ \\
\hline LNF & $186.6 \pm 4.1$ & $191.3 \pm 4.9$ & $204.3 \pm 7.4^{*}$ & $216.8 \pm 8.5^{* *}$ & $188.3 \pm 3.7$ & $190.4 \pm 6.7$ & $197.1 \pm 8.8$ \\
\hline Total & 186.9 & & & &
\end{tabular}

Note: ${ }^{*}-p \leq 0.05,{ }^{* *}-p \leq 0.01$ in relation to the control group

Morphological changes in the retina of rats of experimental group II, which consumed water saturated with $\mathrm{Cr}(\mathrm{VI})$ throughout the experimental period are presented in Fig. 2-4. Compared with the histostructure of the retinal apparatus of the control group of rats (Fig. 1), the signs of cytoarchitectonics violation in all layers of the retina are clearly visualized, the intensity of which increases with the prolongation of the experiment.

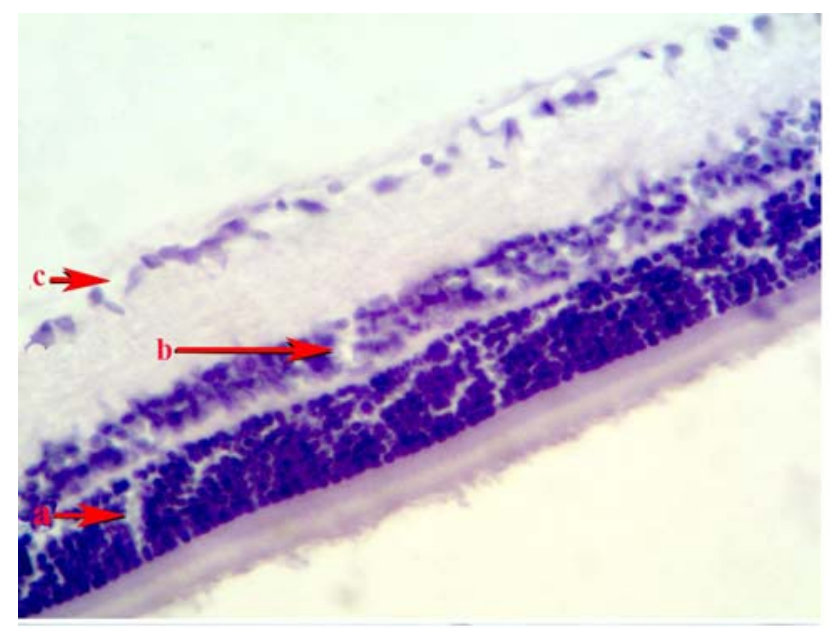

Fig. 2. Retina of rats of experimental group 20 on the 20th day of $\mathrm{Cr}$ (VI) use. Hematoxylin and eosin staining. Magnification $\times 400$. Destructive changes in all layers of the retina: $\mathrm{a}$ - pericellular edema of the cells of the outer nuclear layer; $b$ - the inner nuclear layer, $\mathrm{c}$ - edema of the ganglion layer

After 20 days of rat consumption of xenobiotics in the retina, there were moderate edematous changes in the nuclear layers: the outer nuclear layer, the inner nuclear layer and the layer of ganglion cells. Attention is drawn to the increase in the thickness of the retina, both general and its individual layers (Table 1).

In the photosensory layer of the retina in certain places we observe areas of reduction in the length of the distal segments of rods and cones, but in general the vast majority of their outer and inner segments remained intact (Fig. 2). The thickness of the photoreceptor layer was $35.9 \pm 1.1 \mu \mathrm{m}$, the norm was $35.2 \pm 0.2 \mu \mathrm{m}$. The outer nuclear layer of the retina is cytologically uniform in thickness, but moderately sparse due to homogeneous cell-free zones throughout. A slight thickening of the outer nuclear layer to $38.9 \pm 0.4 \mu \mathrm{m}$, control - $38.5 \pm$ $\pm 0.9 \mu \mathrm{m}$. No changes were observed in the structure of the outer plexiform layer of the retina both at the optical level and according to morphometry. A similar pathohistological picture of the outer nuclear layer was observed in the inner nuclear layer of the retina of rats, but more pronounced. In particular, the ordering and columnar orientation of the cells of the inner nuclear layer with areas of both partial and complete absence of nuclear elements is disturbed. The inner nuclear layer became wider than in intact animals $-28.9 \pm 0.2 \mu \mathrm{m}$ and reached $30.9 \pm 1.3 \mu \mathrm{m}(\mathrm{p} \leq 0.05)$. The thickness of the inner reticular layer of the retina of experimental rats significantly increased and was $57.4 \pm 1.9 \mu \mathrm{m}$, the norm was $55.7 \pm$ $\pm 1.7 \mu \mathrm{m}(\mathrm{p} \leq 0.05)$. Potentially, according to the macroscopic structure, the inner mesh layer remained functioning. The layer of ganglion cells of the retina of animals was moderately thinned and was $16.2 \pm 0.3 \mu \mathrm{m}$, control $16.9 \pm 0.8 \mu \mathrm{m}$. Under the influence of hexavalent chromium, the nuclei of ganglion layer neurocytes had an irregular shape with eosinophilic cytoplasm. The distance between the individual cells in the ganglion layer increased, visible cells with signs of vacuolation and microcystic degeneration. In the layer of nerve fibers, partial branching of axons of multipolar neurons is visualized. In general, after 20 days of consumption of hexavalent chromium, the retina of rats tended to thicken and was equal to $191.3 \pm 4.9 \mu \mathrm{m}$, at the norm $-186.5 \pm 4.1 \mu \mathrm{m}$.

After 40 days of simulation of microelementosis in the retina of rats, increased edema and disturbances of histoarchitectonics were observed in almost all layers: photosensory, external and internal nuclear, external and internal reticular, ganglionic and nerve fiber layer (Fig. 3). The total retinal thickness continued to increase significantly and was $204.3 \pm 7.4 \mu \mathrm{m}(\mathrm{p} \leq 0.05)$, by $9.68 \%$ compared to normal. Edema was observed in the layer of photosensory cells with the presence of a significant number of vacuoles between the outer and inner segments of rods and cones. At the same time it remains uniform in thickness - 35.6 \pm 0.2 microns, at norm $35.2 \pm 0.2$ microns. In the outer nuclear layer, an increase in alternative-edematous changes was observed. The 
number of wide homogeneous diffuse cell-free zones increased between the nuclei of the cell population, which is a sign of pericellular edema. There were single places of mixing of the nuclei of the outer nuclear layer in the layer of photoreceptors. At this stage of the study, the layer thickness continued to gradually increase to $39.4 \pm 1.1 \mu \mathrm{m}(\mathrm{p} \leq 0.05)$.

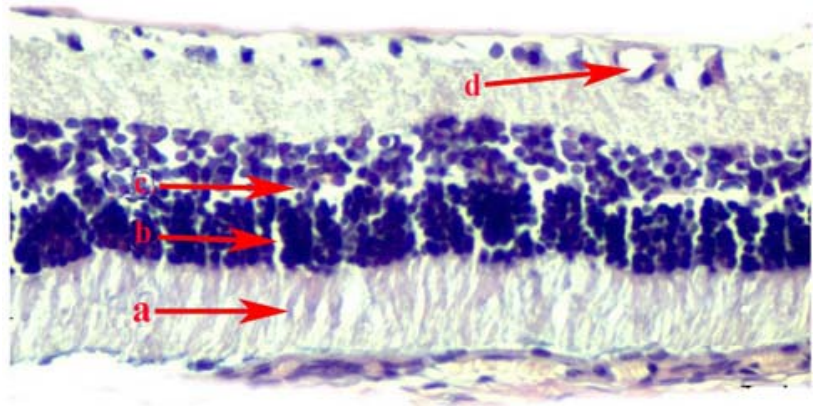

Fig. 3. Retina of rats of the experimental group for 40 days of $\mathrm{Cr}$ (VI) use. Hematoxylin and eosin staining. Magnification $\times 400$. Designation:

$\mathrm{a}$ - edema of the photocell layer of sensory cells, $\mathrm{b}$ - reticular appearance of cells of the inner nuclear layer and $\mathrm{c}-$ cells of the outer nuclear layer due to increased pericellular edema,

$\mathrm{d}$ - edema and vacuolar degeneration of the ganglion layer

The inner mesh layer is difficult to differentiate due to the disorganization of the outer and inner nuclear layers. The thickness of the inner nuclear layer is $40.3 \pm 2.1 \mu \mathrm{m}(\mathrm{p} \leq 0.01)$, which is $39.21 \%$ more than normal. This layer of the retina is irregularly shaped, quite sparse with cells that had different colors. There are many places of movement of cell nuclei of the inner nuclear layer in the outer reticular layer. The inner reticular layer is swollen - $61.7 \pm 2.5 \mu \mathrm{m}(\mathrm{p} \leq 0.01)$, which is $10.81 \%$ more than the control. Throughout it, there is a violation of the longitudinal orientation of the axons of the cells of the inner nuclear layer located here. There is a tendency to thin the ganglion layer and the layer of nerve fibers to $15.3 \pm 1.4 \mu \mathrm{m}$, relative to the control group of animals $-16.9 \pm 0.8 \mu \mathrm{m}$, which is a consequence of atrophic processes. The layer of ganglion neurons undergoes dystrophic changes with the formation of vacuolar cavities of polygonal shape. Neurons of polymorphic structure, nuclei are displaced to the periphery and in some places there are cells with the phenomena of chromatolysis. These signs indicate the death of neurons by apoptosis. Moderately fibrous axons of ganglion cells are visualized in the layer of nerve fibers.

The pathomorphological picture of the retina of rats after 60 days of hexavalent chromium loading was characterized by pronounced disorganization and loss of uniformity of both outer and inner layers (Fig. 4). All layers of the retina without exception have undergone degenerative transformation.

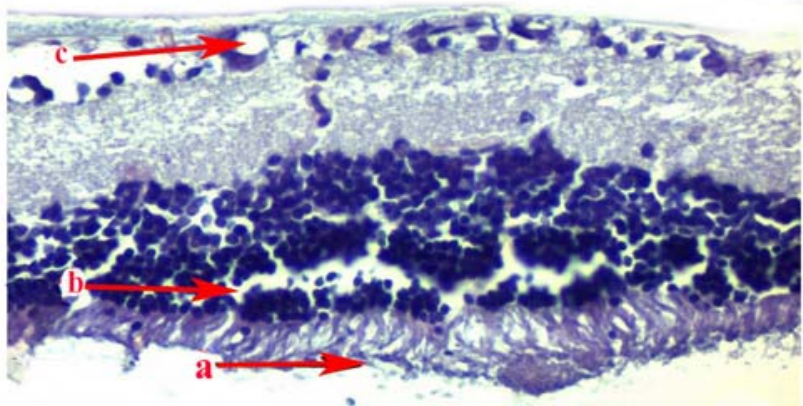

Fig. 4. Retina of rats of the experimental group for 60 days of $\mathrm{Cr}$ (VI) use. Hematoxylin and eosin staining. Magnification $\times 400$. Designation:

a - dystrophic changes of photoreceptor cells, $\mathrm{b}$ - nuclei of the inner nuclear layer with signs of karyolysis, $\mathrm{c}$-disorganization of the layer of nerve fibers with the formation of pseudocysts

The thickness of the ganglion layer increased dynamically and was, respectively, $191.3 \pm 4.9 \mu \mathrm{m}$ for 20 days, $204.3 \pm 7.4 \mu \mathrm{m}$ for 40 days $(\mathrm{p} \leq 0.05)$ and $216.8 \pm 8.5$ $\mu \mathrm{m}$ for 60 the day of the experiment $(\mathrm{p} \leq 0.01)$. In the layer of photoreceptor cells, edema is expressed with the formation of a large number of vacuoles, chaotic arrangement and violation of the structural organization of the processes (fragmentation). In some areas there are places of complete absence of external segments of photoreceptor cells. There are cell nuclei moved here from the outer nuclear layer. The outer and inner nuclear layers due to severe edema have lost cytological order and horizontal orientation of cells and merge with each other. Irregularly shaped cells and nuclei with signs of severe karyolysis. Due to the large number of wide layers between neurons, these layers acquire a reticulate appearance. The thickness of the outer and inner nuclear layers is the largest of all the terms of the experiment $41.32 \pm 1.4 \mu \mathrm{m}(\mathrm{p} \leq 0.01)$ and $43.2 \pm 2.5 \mu \mathrm{m}(\mathrm{p} \leq 0.05)$, respectively, which is more than the norm for $7.85 \%$ and $49.38 \%$. The inner reticular layer is wide $-67.8 \pm 3.6 \mu \mathrm{m}(\mathrm{p} \leq 0.05)$, $23.37 \%$ more than in control rats, sparse and swollen. The processes of neurons of cells from the previous layer are chaotically located everywhere, in different directions, torn in places. The layer of ganglion cells and nerve fibers is slightly thinned $-15.3 \pm 0.5 \mu \mathrm{m}$, the norm is $16.9 \pm 0.8 \mu \mathrm{m}$. There are single preserved ganglion cells. Most multipolar neurons are of various shapes and in a state of karyopyknosis or neurocytolysis. Under the influence of hexavalent chromium, large polymorphic microcystic cavities are formed between the axons of ganglion cells. The nerve fibers themselves with numerous defects and ruptures. These changes indicate the toxic effects of $\mathrm{Cr}$ (VI) on both neurons (nuclear layers) and their processes (reticular layers).

Morphological examination of the retina of rats, which during the whole period of the experiment used together with water Cr (VI) and as a treatment Enterosgel (group III) revealed a very positive dynamics of preservation of retinal cytoarchitectonics and its thickness (Fig. 5-7). 


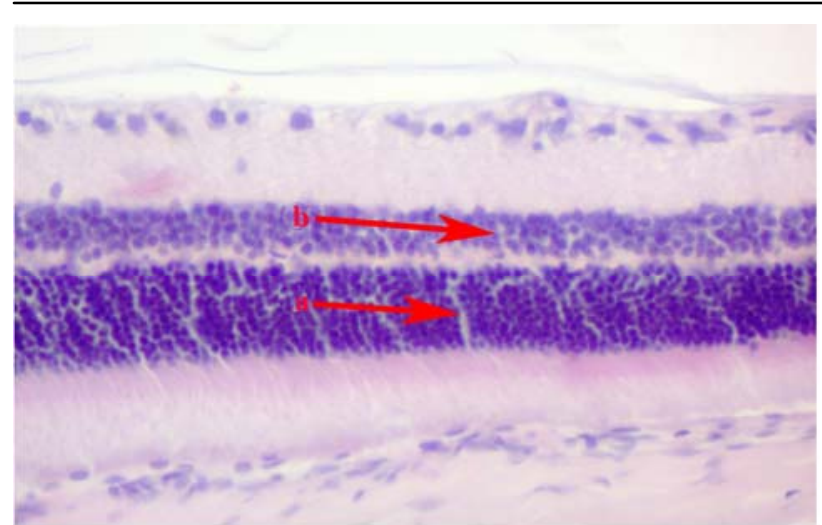

Fig. 5. Retina of the experimental group of rats for 20 days of simultaneous use of $\mathrm{Cr}$ (VI) and Enterosgel. Hematoxylin and eosin staining. Magnification $\times 400$. Designation: a - rarefaction of the outer nuclear and $\mathrm{b}$ - inner nuclear layers due to inconspicuous edema

At the optical level in the retina of rats after 20 days of simultaneous loading of $\mathrm{Cr}$ (VI) and treatment with Enterosgel remained mild and almost imperceptible swelling of the nuclear layers - external and internal (Fig. 5). Cells and nuclei of the correct shape, without alternative signs. The columnar arrangement of the nuclei of the cell population is not disturbed. The thickness of these layers is $37.2 \pm 1.5 \mu \mathrm{m}$ and $29.3 \pm 0.9 \mu \mathrm{m}$, which is very close to the control values $-38.5 \pm 0.9 \mu \mathrm{m}$ and $28.9 \pm 0.2 \mu \mathrm{m}$, respectively. Layer of photosensory cells without signs of damage with preserved outer and inner segments of rods and cones. The outer and inner mesh layers did not undergo alternative - destructive changes. However, against the background of Enterosgel treatment, the undamaged layer of ganglion cells and the layer of nerve fibers are clearly visible, without signs of edema and microcystic degeneration. Its thickness was equal to $-17.7 \pm 1.1 \mu \mathrm{m}$, at the norm $-16.9 \pm 0.8 \mu \mathrm{m}$.

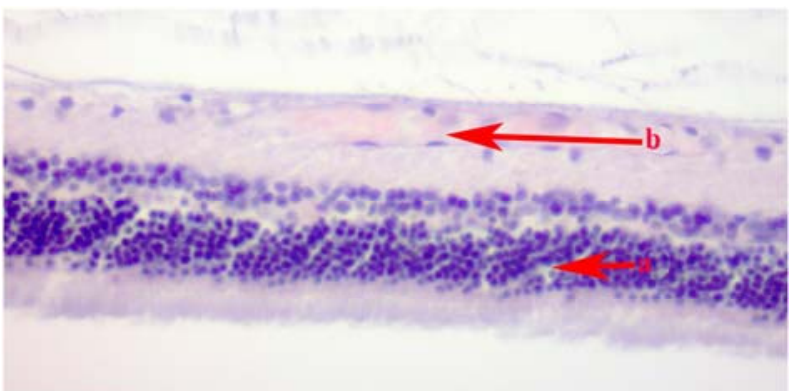

Fig. 6. Retina of the experimental group of rats for 40 days of simultaneous use of $\mathrm{Cr}$ (VI) and Enterosgel. Hematoxylin and eosin staining. Magnification $\times 400$. Designation:

a - rarefaction of the outer nuclear layer due to inconspicuous edema;

$\mathrm{b}$ - edematous thickening of the ganglion layer

After 40 days of treatment with Enterosgel pathological changes caused by hexavalent chromium are slightly enhanced (Fig. 6). The total retinal thickness of rats is moderately thickened to $190.4 \pm 6.7 \mu \mathrm{m}$, relative to control $-186.6 \pm 4.1 \mu \mathrm{m}$. The morphological picture of the photosensory layer did not change compared to the previous period (20 days). This is confirmed by morpho- metric studies, where the thickness of the layer of rods and cones was $35.6 \pm 1.8 \mu \mathrm{m}(\mathrm{p} \leq 0.05)$, at $35.2 \pm 0.2 \mu \mathrm{m}$ in intact rats. Pericellular edema of the outer and inner nuclear layers is preserved, but does not increase and is not reflected in the change in the thickness of the layers. Microcysts are absent. Noticeable non-critical edematous changes of the outer and inner reticular layers. The vast majority of the direction of the processes from the nuclear layers looked completely intact. The thickness of the outer mesh layer during this study period was $13.1 \pm 1.1 \mu \mathrm{m}$ $(\mathrm{p} \leq 0.05)$, an increase relative to the norm by $15.5 \%$. The thickness of the inner mesh layer increased less markedly relative to the outer mesh layer $-57.1 \pm 0.7 \mu \mathrm{m}(\mathrm{p} \leq 0.05)$, relative to the norm by $2.55 \%$. Morphologically, it attracts the attention of the rearrangement of the ganglion layer and the layer of nerve fibers, in the form of the appearance of small areas of stratification of nerve fibers due to slight edema. The condition of neurons is quite satisfactory. At this stage of the study, its thickness is $17.81 \pm 0.92 \mu \mathrm{m}$, with $16.9 \pm 0.8 \mu \mathrm{m}$ in control animals.

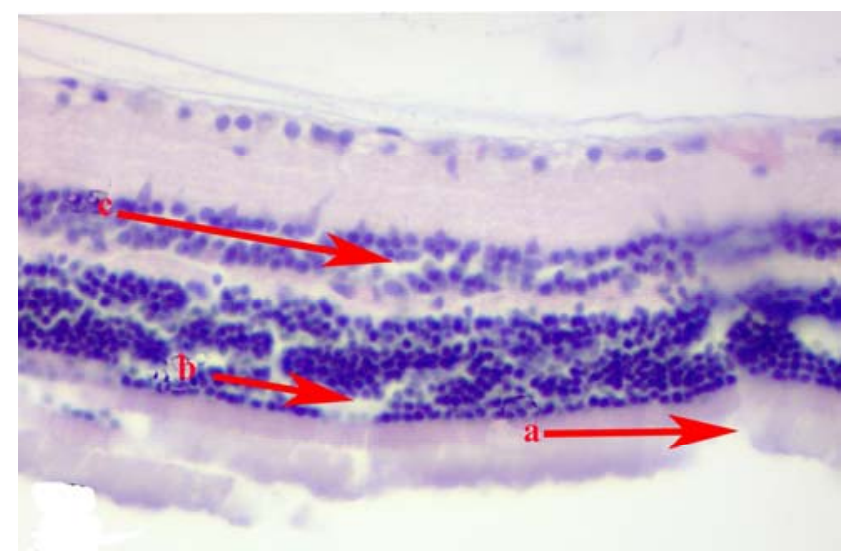

Fig. 7. Retina of the experimental group of rats for 60 days of simultaneous use of $\mathrm{Cr}$ (VI) and Enterosgel. Hematoxylin and eosin staining. Magnification $\times 400$. Designation:

$\mathrm{a}$-destruction of the outer segments of photosensory cells, $\mathrm{b}$ - rarefaction of the outer nuclear and $\mathrm{c}$ - inner nuclear layers

60 days of experimental study of the effect of $\mathrm{Cr}$ (VI) and Enterosgel on the retina of rats showed edematous changes in all layers without exception (Fig. 7). Degenerative changes in the photoreceptor layer appear. Almost throughout the layer there is a vacuolar expansion of the outer segments of the rods and cones with alternating areas of complete destruction of the latter. The outer and inner nuclear layers retained the typical structure, but in some places the distance between the cell nuclei increased due to the formation of microcystic cavities. Morphometrically, the thickness of these layers was close to the comparison group $-38.6 \pm 1.7 \mu \mathrm{m}$ and $30.9 \pm 1.5 \mu \mathrm{m} \quad(\mathrm{p} \leq 0.05)$, respectively. The edematous changes in the outer and inner reticular layers intensified, but without signs of violation of the longitudinal orientation of the fibers. The outer reticular layer is wide $13.4 \pm 1.6(p \leq 0.05), 18.77 \%$ more than in the group of intact animals. The ganglion layer contains bodies of undamaged multipolar neurons, in contrast to their axons, 
which appear slightly thickened and fluffy. According to morphometry, the thickness of this layer is $-17.8 \pm 0.9 \mu \mathrm{m}$ and does not differ from the previous term of the experiment (40 days) $-17.8 \pm 0.9 \mu \mathrm{m}$. Thus, the analysis of the studies shows that the use of Enterosgel improves the morphological picture of the retinal structure in rats with induced Cr (VI) retinotoxicity, which were better expressed at 20 and 40 days, indicating the presence of retinoprotective properties.

\section{Discussion of research results}

Metabolic pathways and toxicity of chromium depend on its valence state - hexavalent chromium [Cr (VI)] is more toxic than chromium (III) compounds [15]. In the cell during the reduction of $\mathrm{Cr}$ (VI) to less toxic compounds - $\mathrm{Cr}$ (V), (IV), (III) many reactive oxygen species (ROS) are formed due to blockade of the I respiratory chain complex in mitochondria [16], which can cause damage to cellular proteins, lipids and DNA [17]. However, under physiological conditions, they are inactivated by an antioxidant defense system [18]. Decreased activity of the antioxidant system under the influence of $\mathrm{Cr}$ (VI) leads to a condition known as oxidative stress (OS) [19]. It has been experimentally proven that oral administration of potassium dichromate caused OS in rabbits, which was accompanied by a significant decrease in glutathione peroxidase, superoxide dismutase and catalase activity, as well as an increase in malonic aldehyde, the end product of lipid peroxidation.

The apoptotic changes of retinal neurons that received water saturated with $\mathrm{Cr}$ (VI) revealed in our study at the cellular level are explained by previous works. Xiao F. and co-authors [16] proved that $\mathrm{Cr}$ (VI) activates caspase-3, which is an irreversible effector enzyme in the implementation of the internal mitochondrial pathway of programmed cell death. Cr (VI) penetrates the bloodbrain barrier, then, like other cationic metals, overcomes the outer membrane of mitochondria by the mechanism of molecular mimicry [20,21].

The drug of choice as a corrector was Enterosgel. According to the literature, Enterosgel, on the one hand, prevents the development of oxidative stress in mitochondria [22], and on the other hand, absorbs toxic substances from the lumen of the gastrointestinal tract, preventing them from entering the systemic circulation [23].

Study limitations. Our studies are limited to morphological and morphometric studies of the retina of rats with $\mathrm{Cr}(\mathrm{VI})$-induced retinopathy.

Prospects for further research. In the future, it is necessary to experimentally investigate changes in the optic nerve under the influence of hexavalent chromium and the possibility of their correction by Enterosgel.

\section{Conclusions}

1. $\mathrm{Cr}(\mathrm{VI})$ - induced retinotoxicity in rats is characterized by pronounced histological and morphometric changes in cytoarchitectonics and retinal thickness, which appear after 20 days, intensify by 40 days and acquire maximum transformations after 60 days of the experiment.

2. The use of Enterosgel improves the morphological picture of the retina of rats with induced $\mathrm{Cr}$ (VI) retinotoxicity, preserves its structure. Positive changes were better expressed on the 20th and 40th day, which indicates the presence of retinoprotective properties.

\section{Conflict of interests}

The authors declare that they have no conflicts of interest.

\section{References}

1. Dudnyk, S. V., Koshelia, I. I. (2016). Tendentsii stanu zdorovia naselennia Ukrainy. Zdorovia natsii, 4 (40), 67-77.

2. Scientific Opinion on the risks to public health related to the presence of chromium in food and drinking water (2014). EFSA Journal, 12 (3), 35-95. doi: http://doi.org/10.2903/j.efsa.2014.3595

3. Yuki, K., Dogru, M., Imamura, Y., Kimura, I., Ohtake, Y., Tsubota, K. (2009). Lead Accumulation as Possible Risk Factor for Primary Open-Angle Glaucoma. Biological Trace Element Research, 132 (1-3), 1-8. doi: http://doi.org/10.1007/s12011-009-8376-Z

4. Park, S. J., Lee, J. H., Woo, S. J., Kang, S. W., Park, K. H. (2015) Epidemiologic Survey Committee of Korean Ophthalmologic Society. Five heavy metallic elements and age-related macular degeneration: Korean National Health and Nutrition Examination Survey, 2008-2011. Ophthalmology, 122 (1), 129-137. doi: http://doi.org/10.1016/j.ophtha.2014.07.039

5. Jung, S. J., Lee, S. H. (2019). Association between Three Heavy Metals and Dry Eye Disease in Korean Adults: Results of the Korean National Health and Nutrition Examination Survey. Korean Journal of Ophthalmology, 33 (1), 26-35. doi: http://doi.org/10.3341/kjo.2018.0065

6. Sharma, P., Bihari, V., Agarwal, S. K., Verma, V., Kesavachandran, C. N., Pangtey, B. S. et. al. (2012). Groundwater Contaminated with Hexavalent Chromium [Cr (VI)]: A Health Survey and Clinical Examination of Community Inhabitants (Kanpur, India). PLoS ONE, 7 (10), e47877. doi: http://doi.org/10.1371/journal.pone.0047877

7. Tumolo, M., Ancona, V., De Paola, D., Losacco, D., Campanale, C., Massarelli, C., Uricchio, V. F. (2020). Chromium Pollution in European Water, Sources, Health Risk, and Remediation Strategies: An Overview. International Journal of Environmental Research and Public Health, 17 (15), 5438. doi: http://doi.org/10.3390/ijerph17155438

8. Apel, W., Stark, D., Stark, A., O’Hagan, S., Ling, J. (2013). Cobalt-chromium toxic retinopathy case study. Documenta Ophthalmologica, 126 (1), 69-78. doi: http://doi.org/10.1007/s10633-012-9356-8

9. Ng, S., Ebneter, A., Gilhotra, J. (2013). Hip-implant related chorio-retinal cobalt toxicity. Indian Journal of Ophthalmology, 61 (1), 35-37. doi: http://doi.org/10.4103/0301-4738.105053

10. Garcia, M. D., Hur, M., Chen, J. J., Bhatti, M. T. (2020). Cobalt toxic optic neuropathy and retinopathy: Case report and review of the literature. American Journal of Ophthalmology Case Reports, 17, 100606. doi: http://doi.org/10.1016/j.ajoc.2020.100606

11. Vashkulat, N. P. (2002). Establish levels of heavy metals in soils in Ukraine. Environ Health, 2, 44-46.

12. Enterosgelum. Available at: https://compendium.com.ua/info/45247/enterosgel /?gclid=Cj0KCQiAhs79BRD0ARIsAC6Xpa WNtWnGca92BMToa94LSBYTztnf8rHzcqgqIYuDB5J18_1AkqghI7gaAvxTEALw_wcB

13. Rybolovlev, Iu. R., Rybolovlev, R. S. (1979). Dozirovanie veschestv dlia mlekopitaiuschikh po konstantam biologicheskoi aktivnosti. Doklady Akademii Nauk SSSR, 247 (6), 1513-1516. 
14. Vit, V. V. (2003). Stroenie zritelnoi sistemy cheloveka. Odessa: Astroprint, 664.

15. Fang, Z., Zhao, M., Zhen, H., Chen, L., Shi, P., Huang, Z. (2014). Genotoxicity of Tri- and Hexavalent Chromium Compounds In Vivo and Their Modes of Action on DNA Damage In Vitro. PLoS ONE, 9 (8), e103194. doi: http://doi.org/10.1371/journal.pone.0103194

16. Xiao, F., Li, Y., Dai, L., Deng, Y., Zou, Y., Li, P. et. al. (2012). Hexavalent chromium targets mitochondrial respiratory chain complex I to induce reactive oxygen species-dependent caspase-3 activation in L-02 hepatocytes. International Journal of Molecular Medicine, 30 (3), 629-635. doi: http://doi.org/10.3892/ijmm.2012.1031

17. Sun, H., Brocato, J., Costa, M. (2015). Oral Chromium Exposure and Toxicity. Current Environmental Health Reports, 2 (3), 295-303. doi: http://doi.org/10.1007/s40572-015-0054-z

18. Velichkovskii, B. T. (2001). Svobodnoradikalnoe okislenie kak zveno srochnoi i dolgovremennoi adaptatsii organizma $\mathrm{k}$ faktoram okruzhaiuschei sredy. Vestnik RAMN, 6, 45-52.

19. Patlolla, A. K., Barnes, C., Yedjou, C., Velma, V. R., Tchounwou, P. B. (2009). Oxidative stress, DNA damage, and antioxidant enzyme activity induced by hexavalent chromium in Sprague-Dawley rats. Environmental Toxicology, 24 (1), 66-73. doi: http://doi.org/10.1002/tox.20395

20. Mary Momo, C., Ferdinand, N., Omer Bebe, N., Alexane Marquise, M., Augustave, K., Bertin Narcisse, V. et. al. (2019). Oxidative Effects of Potassium Dichromate on Biochemical, Hematological Characteristics, and Hormonal Levels in Rabbit Doe (Oryctolagus cuniculus). Veterinary Sciences, 6 (1), 30. doi: http://doi.org/10.3390/vetsci6010030

21. Castellino, N., Aloj, S. (1969). Intracellular distribution of lead in the liver and kidney of the rat. Occupational and Environmental Medicine, 26 (2), 139-143. doi: http://doi.org/10.1136/oem.26.2.139

22. Nikolaiev, V. H., Klishch, I. M., Zhulkevych, I. V., Oleshchuk, O. M., Nikolaieva, V. V., Shevchuk, O. O. (2009). Zastosuvannia preparatu Enteroshel dlia profilaktyky oksydatyvnoho stresu pry hostrii krovovtrati. Visnyk naukovykh doslidzhen, 8, 72-74.

23. Howell, C. A., Mikhalovsky, S. V., Markaryan, E. N., Khovanov, A. V. (2019). Investigation of the adsorption capacity of the enterosorbent Enterosgel for a range of bacterial toxins, bile acids and pharmaceutical drugs. Scientific Reports, 9 (1). doi: http://doi.org/10.1038/s41598-019-42176-z

Received date 20.11.2020

Accepted date 23.12.2020

Published date 30.01.2021

Olena Kuzenko, Postgraduate Student, Department of Ophthalmology, Kharkiv Medical Academy of Postgraduate Education, Amosova str., 58, Kharkiv, Ukraine, 61176,

E-mail: logvinenok26@gmail.com

Yevhen Kuzenko, MD, Associate Professor, Department of Pathological Anatomy, Sumy State University, Rymskogo-Korsakova str., 2, Sumy, Ukraine, 40007

E-mail: yevhen.kuzenko@gmail.com

Yuri Demin, MD, Professor, Department of Ophthalmology, Kharkiv Medical Academy of Postgraduate Education, Amosova st.58, Kharkov, Ukraine, 61176

E-mail: deminprof@gmail.com 